\title{
The Fauna and Ecological Groups of Bivalve Mollusks of Kamashi and Karabakh Reservoirs
}

\author{
Boymurodov Husniddin* and Jabborova Tozagul \\ Samarkand State University, Uzbekistan \\ *Corresponding author
}

\begin{abstract}
A B S T R A C T
\section{Keywords}

Bivalve Mollusks, Kamashi and

Karabakh

Reservoirs

Article Info

Accepted:

24 October 2020

Available Online:

10 November 2020

There are 9 species and 1 subspecies in the reservoirs of the Kashkadarya coast in Karabakh and 6 species and 1 subspecies in Kamashi. In the Kamashi reservoir, peloreophiles make up 57\%, rheophiles $14 \%$ and crenophiles $29 \%$. In the Karabakh reservoir, peloreophiles were found to be $70 \%$, rheophiles $10 \%$, pelolimnophiles $10 \%$ and crenophiles $10 \%$.
\end{abstract}

\section{Introduction}

In aquatic ecosystems, bivalve mollusks are a complex group for research. Their morphological features are important in determining their shell shapes, the presence or absence of teeth. At the same time, the distribution of bivalve mollusks and the large number of individuals play an important role in ecosystems in solving practical problems such as zoogeography, history of freshwater fauna, hydrobiology, environmental monitoring, bioindication and other cases.

\section{Analysis of the topic-related literature}

Bogatov VV, Starobogatov Ya.I. researched on the identification of territorial diversity, taxonomic structure and signs of variability of bivalve mollusks in aquatic ecosystems. Bogatov (2014), Andreev et al., (2009) assess the status of populations and the prevalence of global invasive species of these types.

Alyoxina et al., (2007), Panov et al., al. (2009), Son (2009), Yanovich (2013) conducted some research on the importance of biphasic mollusks in determining water pollution levels; Rijinashvili (2009), Sintyurina and Bigaliev (2009), Kuzmenkin (2015) collected data on the distribution, morphology and resources of bivalve mollusks in different water bodies in the country. The shapes and the water bodies in which tsese types occur are reflected in the researches of ZI Izzatullaev., HT Boymurodov (1992, 2012, 2018, 2019). 


\section{Materials and Methods}

Scientific materials for this research were collected from the Kamashi and Karabakh reservoirs in 2017-2020. The collected materials were analyzed by the methods of VI Jadin (1938-1952), Starobogatov, ZI Izzatullaev (1984), ZI, Izzatullaev, HT Boymurodov $(2009,2018)$.

\section{Results and Discussion}

Kamashi Reservoir is a hydraulic structure built in Kashkadarya region. It was formed in 1957 by blocking the Shurchasoy natural basin with a soil dam, $4 \mathrm{~km}$ from the city of Kamashi. The Karabakh canal, which receives water from the Yakkabog River, flows into the reservoir. As a result of the research, 6 species and 1 subspecies of bivalve mollusks have been found to live in the Kamashi reservoir. They belong to 3 different ecological groups, which belong to peloreophils, renophiles and crenophiles (Table 1). In the reservoir in 2000, 2016, 2018 the species of Sinanondonta, Colletopterum seeds were distributed from bivalve mollusks with fish acclimatized. Sinanondonta gibba is distributed in the waters of the Kamashi Reservoir and its outlet channel, and its density is 0.7 . This species is widely adapted to changes in the hydrological regime of the reservoir. The species Sinanondonta orbicularis and S.puerorum were not found in the reservoir biatops. The reason may be that the variability of the reservoir water regime has shown its effect.

Colletopterum cyreim sogdianum is also common in the Kashkadarya River, from where it passes through canals into the reservoir. In reservoirs, this species was found to have an average of 0.9 per $1 \mathrm{~m} 2$. Colletopterum ponderosum volgense, cocandicum and Colletopterum bactrianum species from the type Colletopterum seed specieswere not found in the reservoir.
Seed species of Euglesia and Kuiperipisidium are distributed in springs of the upper part of the reservoir. Kuiperipisidium issykkulense and $K$. polytimeticum types were found in the waters of springs. Their density was found to be on average 1.1-1.2 per $1 \mathrm{~m} 2$. We encountered many bush shells of Kuiperipisidium issykkulense in the Kamashi reservoir. The reservoir regulates river flow by seasons and years, allowing for redistribution of water across areas, along with canals and other drainage structures. This led to the formation of ecological groups in the watersheds with the spread of species of the families Unionidae, Corbiculidae. Corbicula sor is widespread on the right bank of the reservoir and in the canals around it.

Water, which is the habitat of mollusks, with its number of physical properties, has had a different effect on the distribution, density, morphology and ecology of mollusks, which has led to differences in their density of their population. For example, Corbicula sor has a density of 1.3 per $1 \mathrm{~m} 2$. In the Kamashi Reservoir, C.sor's shell is heart-yellow in color, the front and back are rounded, and the inner wall is white. We observed that they laid eggs in the spring in the scattered areas of the reservoir. With the advent of spring and the rise in water temperature, we have observed the beginning of the development of reproduction, and it lasts from the second half of March to June. We found that the density of Corbiculina ferghanensis and C. tibetensis in the reservoir was $2.1-2.2$ per $1 \mathrm{~m} 2$. There are 3 ecological groups of bivalve mollusks in the Kamashi reservoir. There are 4 types of peloreophiles in stream waters (Sinanondonta gibba, Corbicula sor, Corbiculina ferghanensis, C. tibetensis), reophilus type 1 in stream waters (Colletopterum cyreim sogdianum) and crenophiles type 2 (Kuiperipisidium K.) in spring and spring watersheds. Among them, peloreophiles make up $57 \%$, rheophiles $14 \%$ and crenophiles 
29\%. 2 species of Corbiculina ferghanensis, C. tibetensis distributed in the reservoir are Colletopterum cyreim sogdianum, the most common eurybiont species in terms of density, and the remaining 5 species are Sinanondonta gibba, Corbicula sor,

Kuiperipisidium issykkulense and $\mathrm{O}$. rolutimeticum due to density less than 1.5 per $1 \mathrm{~m} 2$. stenabiont species were identified.

Table.1 Fauna and ecological groups of mollusks of the Karabakh and Kamashi reservoirs (m2 / pcs. $\mathrm{n}=10)$

\begin{tabular}{|c|c|c|c|c|c|c|c|}
\hline \multirow[t]{2}{*}{ № } & \multirow[t]{2}{*}{ Types } & \multirow[b]{2}{*}{ 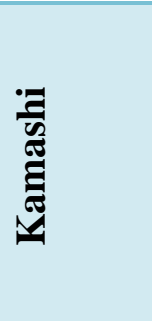 } & \multirow[b]{2}{*}{ 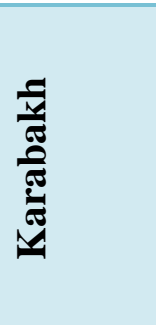 } & \multicolumn{3}{|c|}{ Biotops } & \multirow[t]{2}{*}{ Ecological groups } \\
\hline & & & & 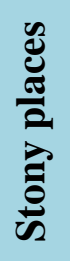 & 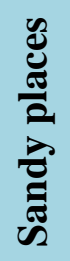 & 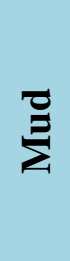 & \\
\hline 1. & Sinanodonta gibba & $0,7 \pm 0,1$ & - & - & - & + & Peloreophil \\
\hline 2. & Sinanodonta orbicularis & - & $0,7 \pm 0,2$ & - & - & + & Peloreophil \\
\hline 3. & Sinanodonta puerorum & - & $0,6 \pm 0,1$ & - & - & + & Peloreophil \\
\hline 4. & Colletopterum bactrianum & - & - & - & - & - & Rheophilus \\
\hline 5. & Colletopterum cyreum sogdianum & $0,9 \pm 0,2$ & $1,0 \pm 0,3$ & - & + & + & Rheophilus \\
\hline 6. & Colletopterum ponderosum volgense & - & - & - & - & - & Pelolimnofil \\
\hline 7 & Colletopterum kokandicum & - & - & - & - & - & Pelolimnofil \\
\hline 8. & Euglesa hissarica & - & $2,1 \pm 0,5$ & - & + & - & Pelolimnofil \\
\hline 9 & Euglesa heldreichi & - & - & - & - & - & Pelolimnofil \\
\hline 10 & Euglesa turkestanica & - & - & - & - & - & Pelolimnofil \\
\hline 11 & Euglesa obliquata & - & - & - & - & - & Pelolimnofil \\
\hline 12 & Euglesa turanica & - & - & - & - & - & Pelolimnofil \\
\hline 13 & Kuiperipisidium terekense & - & $1,8 \pm 0,4$ & - & + & + & Krenofil \\
\hline 14 & Kuiperipisidium issykkulense & $1,1 \pm 0,3$ & & - & + & - & Krenofil \\
\hline 15 & Kuiperipisidium sogdianum & - & - & - & - & - & Krenofil \\
\hline 16 & Kuiperipisidium polytimeticum & $1,2 \pm 0,2$ & - & - & + & - & Krenofil \\
\hline 17 & Kuiperipisidium behningi & - & - & - & - & - & Krenofil \\
\hline 18 & Corbicula cor & $1,3 \pm 0,5$ & $1,2 \pm 0,3$ & - & + & + & Peloreophil \\
\hline 19 & Corbicula fluminalis & - & $1,4 \pm 0,4$ & - & + & - & Peloreophil \\
\hline 20 & Corbicula purpurea & - & $1,7 \pm 0,6$ & - & + & - & Peloreophil \\
\hline 21 & Corbiculina tibetensis & $2,1 \pm 0,7$ & $2,4 \pm 06$ & + & + & + & Peloreophil \\
\hline \multirow[t]{2}{*}{22} & Corbiculina ferghanensis & $2,2 \pm 0,3$ & $2,8 \pm 0,7$ & + & + & + & Peloreophil \\
\hline & Total species: & 7 & 10 & 2 & 10 & 8 & \\
\hline
\end{tabular}

Karabakh Reservoir is located $15 \mathrm{~km}$ from the center of Yakkabog district. It is mainly flooded by the Yakkabog River and two rivers in the Gissar region and replenished by the Kyzyldarya River. The Karabakh reservoir was commissioned in 1977. Thus, as a result of our research, it was determined that 9 species and 1 subspecies of bivalve mollusks live in the bbottoms of the Karabakh reservoir, which belong to 4 families and 6 
genera (Table 1). With the acclimatization of white grass carp and common catfish, the Chinese toothless mollusk: Sinanodonta orbicularis, $S$. ruerorum, came to the Karabakh reservoir by chance. In these fish, the larvae of Chinese toothless (gloxidian) parasitize exist. Today, these mollusks are widespread in all artificial and natural water bodies of Uzbekistan. Sheep breeds occur naturally in the Amudarya and Syrdarya waters. Sinanodonta occur in the Karabakh Reservoir. Ruerorums are 0.6 pieces per $1 \mathrm{~m} 2$ at depths of 1-2.5 m. The water temperature of the Karabakh reservoir affects not only the growth and reproduction of mollusks, but also plays an important role in their distribution and territorial distribution in the watershed. The Sinanodonta orbicularis reservoir averaged 0.7 grains per $1 \mathrm{~m} 2$ distributed in the lateral biats.

The absence of representatives of Sinanodonta gibba, Colletopterum bactrianum, Colletopterum ponderosum volgense and Solletopterum kokandicum in the middle part of Kashkadarya in the reservoir proves that it is not directly connected with the river. Colletopterum cyreum sogdianum species are widespread on the right and left banks of the reservoir, where their density is very low. However, as in the middle part of Kashkadarya, the Karabakh reservoir also contains sandy biotopes, so only members of the Corbiculidae family can be found in such areas. Their density is lower than that of the river, which is explained by the frequent and sharp fluctuations of the reservoir level.

Two-stage mollusks spread in the areas where the river sand dunes sank to the bottom of the reservoir. Corbicula cor species are distributed on the right and left banks of the reservoir, and their density is lower than other types of water - 1.2 per $1 \mathrm{~m} 2$. In addition, Corbicula fliminalis, C. purpurea occurs in 1.4-1.7 per $1 \mathrm{~m} 2$ in the reservoir. Both representatives of the Corbiculina genus - S. tibetensis and C. ferghanensis - are found in the reservoir. Their density is 2.4-2.8. There are $60 \%$ of mollusk species in the middle part of Kashkadarya in the Karabakh reservoir, but they differ in species diversity. This difference is directly related to the source of water intake of the Karabakh reservoir. Although the reservoir is located in the Kashkadarya basin, it does not receive water from the river, but the reservoir was formed by the inflow of other mountain rivers. Euglesa hissarica and Kuiperipisidium poplars are found in 1.8-2.1 per $1 \mathrm{~m} 2$ area in the part of the reservoir where water is poured into the reservoir by springs. 7 species of peloreophiles live in reservoir muds (Sinanodonta ruerorum, Sinanodonta orbicularis Corbicula cor, C.purpurea, C. fluminalis, Corbiculina tibetensis, $C$. ferganensis), 1 reophilus live in stream waters (Colletopterum cyreum sogdianum), 1 species in streams hissarica) and crenophil 1 species (Kuiperipisidium poplar) live in springs. In the reservoir, peloreophiles make up $70 \%$, rheophiles $10 \%$, pelolimnophiles $10 \%$ and crenophiles $10 \%$. We found that 3 species were distributed in the reservoir, Corbiculina tibetensis, C. ferganensis and Euglesa hissarica, are the most common eurybiont species, and 7 species are stenobiont species distributed in small biatopes.

In summary, 9 species and 1 subspecies are found in the Kashkadarya coastal reservoirs in Karabakh and 6 species and 1 subspecies in Kamashi. In the Kamashi reservoir, peloreophiles make up 57\%, rheophiles $14 \%$ and crenophiles 29\%. In the Karabakh reservoir, peloreophiles were found to be $70 \%$, rheophiles $10 \%$, pelolimnophiles $10 \%$ and crenophiles $10 \%$.

\section{References}

Алёхина Г.П. Мисетов И.А. Пузакова М.В. 
Размерно-возрастная структура environmental indicators // Integrated популяции двустворчатых моллюсков среднего течения реки Урал и её притоков // Вестник Оренбургского государственного университета, 2007. №75. - С. 18-20.

Panov V.E., Alexandrov B., Arbaciauskas K., Binimelis R., Copp G.H., Grabowski M., Lucy F., Leuven R.S.E.W., Nehring S., Paunovic M., Semenchenko V., Son M.O. Assessing the risks of aquatic species invasions via European inland waterways: from concepts to Environmental Assessment and Management, 2009. 5. 110-126.

Сон M.O. Моллюски-вселенцы на территории Украины: источники инаправления инвазии // Российский журнал биологических инвазий, 2009. № 2. - C. 37-48.

Boymurodov Kh.T. The degree of content of natural radionuclides in mollusks // Uzbek Biological journal. -Ташкент, 2011. -№5. -P. 41-42.

\section{How to cite this article:}

Boymurodov Husniddin and Jabborova Tozagul. 2020. The Fauna and Ecological Groups of Bivalve Mollusksof Kamashi and Karabakh Reservoirs. Int.J.Curr.Microbiol.App.Sci. 9(11): 3476-3480. doi: https://doi.org/10.20546/ijcmas.2020.911.414 